\title{
THE EFFECTIVENESS OF TEACHING PRONUNCIATION THROUGH JAZZ CHANTS METHOD
}

\author{
Nurhayati ${ }^{1}$, Nurhamdah ${ }^{2}$ \\ English Program, Tarbiyah Faculty, State Islamic Institute of Parepare ${ }^{12}$
}

\begin{abstract}
This study expected to find out the effectiveness of teaching pronunciation through jazz chants and the students' response toward the implementation of jazz chants method in teaching pronunciation at the eight grade of MTsN Parepare. The result of this research was expected to be useful information in the English teaching and learning process especially in the pronunciation teaching. This research applied pre-experimental method, with two group pre-test and post-test design. The samples of the research were consisted of 27 students from five classes taken from the population at the eight grade students of MTsN Parepare first semester in Academic Year 2018/2019.The result of the data analysis showed that the students' pronunciation abilitywas improved. It could be showed from the result of the tobtained value (7.698) was higher than t-table value (1.706). Those indicated that $\mathrm{H}_{0}$ was rejected and $\mathrm{H}_{\mathrm{a}}$ was accepted. It meant that the students' pronunciationwas able increased by using jazz chants method. Besides that, the result of the questionnaire showed that most of the students agree and had a positive response in learning pronunciation by using jazz chants method. It could be showed from the result of the cumulative percentage on the fifteen items of the questionnaire was 89,28 (very strong), while the cumulative score that they got the questionnaire was 1808 (strongly agree). Based on the result of data analysis above, the researcher then concluded that the students' pronunciation ability was improved and it is effective to teaching pronunciation through jazz chants at the eight grade of MTsN Parepare.
\end{abstract}

Keywords: Pronunciation, Jazz Chants 


\section{Introduction}

Pronunciations the most important element in speaking skills. It relates to how human say words and receive sounds from the spoken word. Communication will run smoothly if there is a good understanding between the speaker and the listener. Understanding will be obtained if the person who is advancing the conversation understands and speaks the voice accurately. Although we fluent in English without good pronunciation skills, so our English will be difficult to understand by native speakers and also, we will have difficulty understanding English from native speakers when they speak quickly.

Learning English pronunciation is not easy. According to research from Primanda and Monika, students have some difficulties to learn it. Firstly, they are lack of pronunciation knowledge due to their inadequate English background. Secondly, it is seldom for them to practice speaking, which also has some disadvantages in pronunciation practice. Next, the teaching and learning process in the classroom focuses more on writing. Lastly, there are too many activities proposed by the materials which result in the lack of time.

In addition, which causes students to trouble or sometimes find problems in pronunciation when they are talking, read or hear a word in English. It might be caused by internal and external factors. Internal factors come from the learners themselves such motivation, interest, and aptitude. While the external factors come from outside of the learners, such as learning materials, and the teacher's ability in handling the English teaching-learning process.

Therefore, learning English should be done in a fun way and understand what they learn in order to generate motivation and interest of students in learning English, exactly in mastering pronunciation. Fun learning will arise when the method used in delivering the material is interesting. It is important as a teacher how to make students understand the pronunciation of the word in English well. 
Music is one of the learning media that can have a positive impact on the learning process. Because using music students will generate more motivation to learn. Music does not always have to be so that the learning process can take place but with music, the learning process will be more fun and certainly not boring, it also gives better results. Learning by not using music makes students tense and difficult to accept learning material. But with music students become relaxed and ready to receive learning materials easily so that they are stored in long-term memory.

A study by George Lozanov proved that music is very useful in the learning process. Lozanov developed a method to accelerate language training through suggestion, relaxation and music at the University of California at Irvie and found that students who listened to music won points 8 and 9 higher than those who listened to recorded verbal relaxation messages. In addition to being able to practice learning language music also stimulates rhythmic thoughts, meaning music trains movement coordination with rhythm, learning and understanding music is a process of learning to understand rhythm. One method of learning that uses music is a learning method of jazz chants. So that the researcher interested to do a research about teaching pronunciation through jazz chants. The researchers expect music in jazz chants to have a good impact on students, especially in pronunciation learning.

The researcher chooses MTsN Parepare in eight grade as a subject of the research because based on problem survey which has been discovered by the researcher and find that there is a lack ability of pronunciation. This case motivates the researcher to find an appropriate solution to solve that problem, how to make the student understand the lesson well, not bored and can enjoy the lesson given. There are actually many methods that can be done for pronunciation learning to be effective in the classroom. But the method of choice of researchers is the method of jazz chants.

Jazz Chantsare Carolyn Graham's snappy, upbeat chants and poems that use jazz rhythms to illustrate the natural stress and intonation patterns of conversational American English. By using jazz chants to teaching English especially pronunciation 
to the class, It's a very effective and enjoyable way to learn because jazz chants help the student to get the "feel" of American English. The student learns the stress, rhythm and intonation patterns by "doing" them and also can motivate students to pronounce English as often as possible with fun. They will enjoy the repetition of words in verse and can memorize quickly.

Jazz chants are simple techniques because they correspond to natural language, no special skills are required in composing this short chant. All we need is we practice it and sing it so that these short songs are easy to remember. So, this jazz chant emphasizes the number of syllabuses on words, phrases or sentences. Jazz chant was not only for young children but also English learners at all levels, as jazz chant teaches active learning.

In accordance with the background of students at the eight grade ofMTsN Parepare, they are still less good in pronunciation learning, they also need English teaching methods especially in pronunciation teaching that can make the spirit and feel no longer bored in learning English. Therefore researchers use jazz chants method so that by using the method that researchers hope that students can enjoy lessons and teaching pronunciation to be effective.

\section{Method}

The research is design pre-experimental design (the one group pre-test posttest). This design as follow:

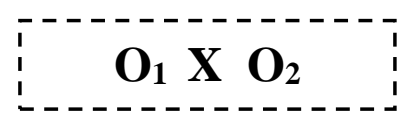

The research done at the Eight Grade at MTsN Parepare for English subject and the duration is 1 month.

The population of this research was the second year of students MTsN Parepare in academic 2017/2018 which consisted of five classes so the totally of population are 142 students. The researcher used purposive sampling technique and chose the VIII.4, which was consists of 27 as the sample in this research. 
Table.1 Students' data of MTsN Parepare in academic year 2017/2018

\begin{tabular}{ccc}
\hline No. & Class & Number of Students \\
\hline 1 & VIII.1 & 29 \\
2 & VIII.2 & 29 \\
3 & VIII.3 & 30 \\
4 & VIII.4 & 27 \\
5 & VIII.5 & 27 \\
\hline \multicolumn{2}{c}{ Total of Students } & 142 \\
\hline
\end{tabular}

Source: MTsNParepare2018

The instrument of this research was objective test in form of 31 item number of the test. These tests were applied in pre-test and post-test. The test focused to improve students' pronunciation. The pre-test would be intended to see student's pronunciation skill before giving treatment, while the post-test would be intended to know the student's improvement in pronunciation. The researcher used another media in measuring student's pronunciation before applying the Jazz Chants in the pre-test.

Table 2 Rating Scale for Pronunciation Test

$\begin{aligned} & \text { Pronunciation is very slightly } \\ & \text { influenced by the mother tongue. } \\ & \text { Two or three mirror grammatical } \\ & \text { and lexical errors. }\end{aligned}$
$\begin{aligned} & \text { Pronunciation is slightly } \\ & \text { influenced by the mother tongue. }\end{aligned}$
$5 \begin{aligned} & \text { A view minor grammatical and } \\ & \text { lexical errors. But most utterances } \\ & \text { phonological errors, some of which } \\ & \text { causes confusion. } \\ & \text { Pronunciation seriously influenced by } \\ & \text { the mother tongue with errors causing }\end{aligned}$
$\begin{aligned} & \text { Pronunciation is still moderately } \\ & \text { influenced by the mother tongue } \\ & \text { but not serious phonological } \\ & \text { errors. A few grammatical and } \\ & \text { lexical errors but only one or two } \\ & \text { major errors causing confusion. }\end{aligned}$


Table 3 Guideline for reviewing the students' pronunciation

\begin{tabular}{ccc}
\hline No & Classification & Score \\
\hline 1 & Excellent & $5.00-6.00$ \\
2 & Very Good & $4.00-4.99$ \\
3 & Good & $3.00-3.99$ \\
4 & Poor & $2.00-2.99$ \\
5 & Very Poor & $1.00-1.99$ \\
\hline
\end{tabular}

Table 4 The rating score of interest category

\begin{tabular}{cc}
\hline Score & Category \\
\hline $67-75$ & Very interested (very positive) \\
$58-66$ & Interested (Positive) \\
$49-57$ & Neutral \\
$40-48$ & Uninterested (negative) \\
$32-39$ & Very uninterested (very negative) \\
\hline
\end{tabular}

The table above means that the student was said to have strongly interested when the mean score is 67 up to 75; they were said to have interested in the mean score is between 58-66; they were said to have moderate interested if the mean score is between 49-57; they were said to have uninterested if the mean score is between 40-48; and they were said to have strongly uninterested if the mean score is between 32-39.

Table 5 The rating percentage of the students' interest score

\begin{tabular}{cc}
\hline Score & Category \\
\hline $81-100$ & Very Positive \\
$61-80$ & Positive \\
$41-60$ & Neutral \\
$21-40$ & Negative \\
$0-20$ & Very Negative \\
\hline
\end{tabular}

\section{Result}


Based on the result of pretest analyzed in the table above, it was stated that the total score of this test ranges from one to twentieth seven. The highest total score was achieved by students 22 with five total score. On the other hand, the students 15 and 21 achieve one as the lowest total of the score. However, the overall students achieve 2.41 as the average score for their pronunciation is "poor" before learning by using jazz chants method. In the pre-test it can be seen that there was 3 students who got score 1 (11.1\%), 13 students got score 2 (48.1\%), 9 students got score 3 (33.3\%), 1 student got score 4 (3.7\%), 1 student got score $5(3.7 \%)$. The highest frequency was 13 at score 2 , and the total frequency was 27 .

Data in posttest, there twentieth seven students who participated in this study. Two students (S6 and S22) got six scores as the highest total score and three students (S9, S15, and S16) got two scores as the lowest total score achieved by the students in this post-test. Wholly, the result of the post-test score analysis indicates that the students have achieved 3,96 as the total average score in the posttest which means that the quality of the students' pronunciation after getting treatment using jazz chants method is "good".

In the pre-test it can be seen that there was 3student who got score $2(11,1 \%)$, 5 students got score 3 (18.5\%), 11 students got score 4 (40.7\%), 6 students got score 5 (7.4\%), 2 students got score $6(7.4 \%)$. The highest frequency was 11 at score 4 , and the total frequency was 27.

The result of the table score of pretest and posttest shows that there was a difference between the pretest and posttest result. The students get significant improvement by gaining score before and after treatment. It means that the students get improvement in their pronunciation after learning by using jazz chants method. The improvement can be measured by taking a look the maximum and the minimum score in the pre-test and post-test in which one (1) is the minimum score in the pretest while two (2) is the minimum score of posttest. On the other hand, five (5) is the maximum score in the pretest, while six (6) is the maximum score of the posttest. Furthermore, there were two (2) students got the maximum score in the posttest. 
In addition, the students' progress in learning also be measured by comparing the students gain score in pretest 2.41 and the students gain score in posttest 3.96. If the two-gain score is taken into account the student's pronunciation quality before and after treatment, we may then state that the quality of the students' pronunciation increased from "poor" to "good".

Table 6 Paired Sample Test

\section{Paired Differences}

Mean Std. Deviation Std. Error Mean

t df

Sig. (2-tailed)

95\% Confidence

Interval of the

Difference

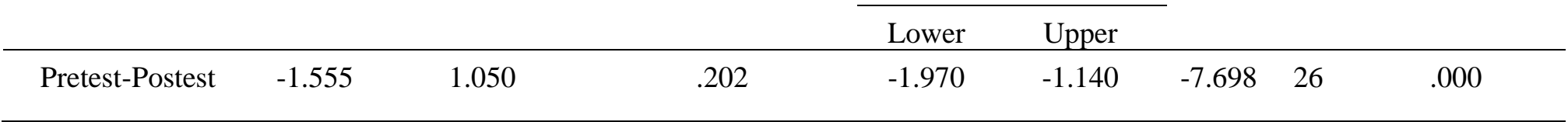

From the table of Paired Sample Test above, it shows that the df is 26, mean difference is 1.555 , standard error difference is 0.20208 , the lower difference interval is 1.970 the upper difference interval is 1.140 , $t_{0}$ is 7.698 while $t$ table is $1.706\left(t_{0}>t\right.$ table) and sig. 0.000. So, it can be concluded that the students' pronunciation skill by using jazz chants method is significantly better after getting the treatment. So, the null hypothesis $\left(\mathrm{H}_{0}\right)$ is rejected and the alternative hypothesis $\left(\mathrm{H}_{\mathrm{a}}\right)$ is fail rejected.

The researcher description of the data collected through pronunciation test to improve the student's pronunciation ability by using Jazz Chants method, it was supported by the student's score of pre-test and post-test in the experimental class. Students mean score after presenting material by using Jazz Chants method in teaching was better than after giving the treatment.

Jazz Chants method that has been taught to the students make them more enjoy and fun to study English because the material taught used strategies that are appropriate to the conditions of students. Thus, making students active in the learning process. In this chapter, the researcher presents the description of findings of the implementation of jazz chants method to improve students' pronunciation ability. 
From 8 positive and 7 negative questionnaires. Most of the students' answered very positively according to the Likert's scale. Based on Likert's scale that the students' very interest in learning pronunciation by using jazz chants.

The result show that the cumulative percentage on the fifteen items of the questionnaire was 89.28 (Very Strong), while the cumulative score that they got the questionnaire was 1808 (Strongly Agree).

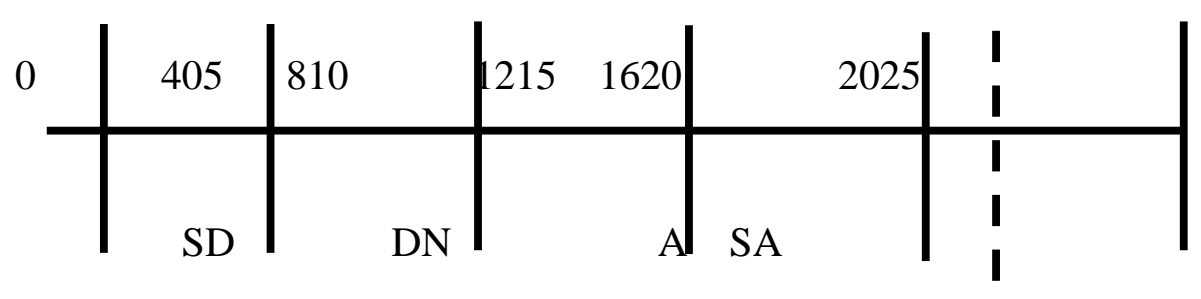

180

\section{Discussion}

Jazz Chants are the rhythmic expression of Standard American English as it occurs in situational contexts. The Jazz Chants included in the book and recorded on the accompanying tape are designed as a language acquisition tool to develop the student's appreciation of the rhythm and intonation patterns of Spoken American English. Just as the selection of a particular tempo and beat in jazz may convey powerful and varied emotions, the rhythm, stresses and intonation patterns of the spoken language are essential elements for the expression of feelings and the intent of the speaker. (Carolyn Graham, 1978)

The students made a lot of mistakes in pronouncing some words. They spoke naturally without stress and intonation. They read the test with the same intonation and pronounced the words with unstressed. For examples dances /da:nces/, surprised /su:praized/, baby /ba:bi/, unique /u:nikui/, television/televizn/ and celebration /selebreifn/. Furthermore, many faults in pronouncing vowels sound. The students cannot pronounce the word with the correct sound. They were only able to use the 
sounds $/ \mathrm{a} /, / \mathrm{i} /, / \mathrm{l} /, / \mathrm{e} /, / \mathrm{o} /$ and error in pronounce the other vowel sounds like $/ \mathrm{iy} /, / \Lambda /$, /eiy/, /ow/, /iuw/. For examples, music /musik/, object /objek/, fortunately /fortunateli/, importance /importance/ and etc. The problem occurs because the sounds are not present in their first or mother language. So, they tend to replace it with the sounds of language that approaching, which they can produce. But, it was different from the posttest result. Their pronunciation was better.

The writer concluded that teaching pronunciation was effective by using jazz chants because when she applied this method to students, the students really looked enthusiastic in the learning process. The existence of chants helped the students more enjoy and fun in the class. So, they could easily to understand the material was given by the writer about some situational context of the conversation and knew the correct stress and intonation when they did it. Thus, studying with chants would not be really difficult for the students. They enjoy the chants and happy because they most of them liked to sing.

But the problem that they face mostly is lack of pronunciation knowledge due to their inadequate English background and also, they seldom to read or practice speaking in English. The students got trouble when reading the text and practice the conversation that is given by the writer. Therefore, good pronunciation will avoid misunderstanding in communication. Actually, the sound system of English was two that is the segmental aspect and supra segmental aspect, the segmental aspect was consonant and vowel, and supra segmental aspects were rhythm, stress, and intonation. According to Marianne Celce Murcia in the same chapter, to be effective in teaching pronunciation, it is essential to have an understanding of how the speech sounds of English are produced. In this research the writer focuses on teaching pronunciation of supra segmental aspects that is rhythm, stress, and intonation. Moreover, teaching pronunciation should be interesting for students, so the writer took chants that is close by daily life conversation of the students.

According to Marie Kretz, they stated that the jazz chants method allows for a creative classroom environment and engages teachers in the creative process. It is 
proved by the writer when she taught in class. The writer gave a sheet to students about the chants so they could easily to read the text. When students sang the chants, they pay attention to the writer's explanation about the correct stress and intonation in every line of the chants, they also more active in responding the writer, and also enjoyed the repetition of the line in the chants. The students did not feel bored during the learning process because the writer divided the class in two parts so they could enthusiastic when between of two-part practice the chants with clapping and a loud voice. Carolyn Graham stated that particular tempo and beat in jazz may convey powerful and varied emotions, the rhythm stresses and intonation patterns of the spoken language are essential elements for the expression of feeling and the intent of the speaker. The natural rhythms and humor of the chant are highly motivating and effectively in classroom practice. It is proved by the writer when she taught in class, the students looked really motivated to studied.

\section{Conclusions}

Based on the finding and discussion in the previous chapter, There is a significant difference between the students' pronunciation ability at the eight grade of MTsN Parepare before and after giving treatment. It is proven the mean score of pretest that is 2,41 then improved to 3,96 as the mean score of post-test. It means that the quality of the students' in pronunciation ability improved from "very poor" to "good" after using Jazz Chants method in giving treatment. The use of Jazz Chants method is effective to teaching pronunciation to improve students' pronunciation ability at the eight grade of MTsN Parepare. It is proven by the t-test value that is 7.698 which is higher than 1.706 as the t-table value.

The students' response to the implementation of jazz chants in teaching pronunciation were very positive, students really looked enthusiastic, they are very happy and fun during the learning process. It is proven by the students' response of a questionnaire, the cumulative percentage on the fifteen items of the questionnaire was 89,28 (very strong), while the cumulative score that they got of the questionnaire was 1808 (strongly agree) 


\section{References}

Avery, Peter and Susan Erhlich. 1992, Teaching American Engliish pronunciation, New York, Oxford University Press.

Celce-Murcia Marianne, dkk., 1996, Teaching Pronunciation: a reference for teachers of English to speaker of other languages, Cambridge, Cambridge University Press.

Celce-Murcia, Marianne. 2006, Teaching English asa a Second or Foreign Language: Third Edition, Singapore: Heinle\&Heinle.

Dewanti, Primanda and Monika Widyastuti S. 2015, Improving Students Pronunciation Using Jazz Chants, UNNES ELTLT (English Language Teaching, Literature, and Translation) Internasional Conference Proceedings, October 2015

Gilakjani, Abbas Pourhosein, 2016, English Pronunciation Instruction: A Literature Review, International Journal of Research in English Education, Vol. 1 No. 1.

Graham, Carolyn. 1978, Jazz Chants. New York: Oxford University Press.

Heaton, J.B. 1989, Writing English Language Tests, Longman Handbook for Language Teacher, United States of America: Longman.

Harmer, Jeremy. 1991 The Practice of English Teaching. Third Edition,Longman.

Kelly, Gerald. 2000, How to Teach Pronunciation, England: Longman Pearson Education Limited.

Kenworthy, Joanne. 1987. Teaching English Pronunciation, Longman Hand Book for Language Teacher, New York: Longman Group UK Limited.

Lado, Robert, 1994. Language Teaching: A Scientific Approach. New York: McGrow-Hill.Inc.

Lumintu, Muhammad Jona, 2015 "The Use of Jazz Chants to Improve Young Learners' Mastery of Body Parts Vocabulary (An Action Research at 5th Graders of SDN Sekaran 02, Gunungpati-Semarang in the Academic Year of 2014/201" Final Project Report; English Department Faculty Of Languages And Arts Semarang State University.

Oxford 2008, Oxford Learner's Pocket Dictionary, The Fourth Edition: Oxford University Press. 
Peralta, Maribel and Guadalupe Quito, 2010 "The Use of Jazz Chants for Children In The Teaching learning Process Of English", A Script, University Of Cuenca Philosophy Faculty English And Literature School.

Ridwan,dkk.2005. “Rumusdan Data DalamAnalisisStatika”. Bandung :Alfabeta

S., Ayu Ahmad, 2016, "Improving Pronunciation Skill Through Tongue Twister a Classroom Research at the Eighth Grade of SMPN 2 KuloKab. SidenrengRappang”, Unpublished Skripsi STAIN Parepare.

Sugiyono, 2012. MetodePenelitianPendidikanPendekatanKuantitatif, Kualitatif, $R \&$ D. Bandung: Alfabeta.

Widyaningsih 2017, "Improving the students' pronunciation ability of the second grade students of SMP Negeri 2 Parepare Through Audio-Lingual Method" Unpublished Skripsi STAIN Parepare.

Yates, Janes. 1995. Pronounce It Perfectly in English. United State of America Barron's Educational Series.

Arimurti, Dian Elements of Pronunciation. Retrieved from http://repository.ut.ac.id/4859/1/PBIS4101-M1.pdf accessed on April, $25^{\text {th }}$ 2018

Kretz, Marie, Music in the Classroom : www.mediafire.com/file/aquhyunbycjju8x/music_in_the_Classroom_Marie Kretz.doc accessed on Mei 24, 2018.

Thalib, Hariani, Anwar, Mujahidah. 2018. Implementing Listen and Imitate Technique to Improve Pronunciation Skill. Journal Inspiring: Vol. 1 No. 1 2018.

Thompson, Shirley, Jazz Chants AE American English, online: https://americanenglish.state.gov/files/ae/resource_files/teaching_with_jazz_c hants_0.pdf accessed on Thursday, March $8^{\text {th }}, 2018$

Wikipedia, Jazz Chants, https://en.wikipedia.org/wiki/Pronunciation (Mei, 24 2018) 